OECDpublishing

PRODUCTIVITY SPILLOVERS FROM MULTINATIONAL ACTIVITY TO LOCAL FIRMS IN IRELAND MATTIA DI UBALDO MARTINA LAWLESS IULIA SIEDSCHLAG

OECD PRODUCTIVITY WORKING PAPERS

November 2018 No. 16 


\section{OECD PRODUCTIVITY WORKING PAPERS}

The OECD Productivity Working Papers are associated with the Global Forum on Productivity that provides a forum for mutual exchange of information and fosters international co-operation between public bodies with responsibility for promoting productivity-enhancing policies, including in undertaking joint policy analysis. It offers a platform for exchanging views, experiences and information, institutional and governance arrangements and government structures, with a view towards developing better policies. The Forum extends existing work in the OECD through a wellprioritised and coherent stream of analytical work serving the policy research needs of participants on the drivers of productivity growth.

This paper has been authorised for publication by Luiz de Mello, Director, Policy Studies Branch.

OECD Productivity Working Papers should not be reported as representing the official views of the OECD or of its member countries. The opinions expressed and arguments employed are those of the author(s).

Comments on OECD Productivity Working Papers are welcome and may be sent to: productivity@oecd.org

OECD Productivity Working Papers are published on: oe.cd/productivity

Series: OECD Productivity Working Paper Series

ISSN 2413-9424

Please cite this paper as:

Di Ubaldo, M., Lawless, M. and Siedschlag, I., "Productivity Spillovers from Multinational Activity to Local Firms in Ireland", OECD Productivity Working Papers, 2018-16, OECD Publishing, Paris.

This document and any map included herein are without prejudice to the status of or sovereignty over any territory, to the delimitation of international frontiers and boundaries and to the name of any territory, city or area.

(C) OECD (2018)

You can copy, download or print OECD content for your own use, and you can include excerpts from OECD publications, databases and multimedia products in your own documents, presentations, blogs, websites and teaching materials, provided that suitable acknowledgment of OECD as source and copyright owner is given. All requests for commercial use and translation rights should be submitted to rights@oecd.org. 
ABSTRACT/RÉSUMÉ

\section{Productivity Spillovers from Multinational Activity to Local Firms in Ireland}

As well as their direct effects on output and employment, the attraction of foreign direct investment is sometimes argued to provide further economic benefits through spillover effects that potentially increase the productivity performance of domestic firms. Empirical evidence on these indirect effects has however tended to be mixed. This paper uses Irish firm-level data on both manufacturing and services firms to re-examine and update evidence on intra-industry and intra-region spillovers and then extends the previous research by examining if spillovers are more likely to occur through supply chain linkages. In addition, we consider the heterogeneity of investors and allow the spillover effects to differ for foreign affiliates owned by EU and non-EU based parent companies. Finally, we examine the role of domestic firms' absorptive capacity in conditioning the effects of spillovers from multinationals on their productivity. Overall, we find limited evidence or a negative link between the presence of foreign-owned firms and the productivity of domestic firms in the same industry or the same region. Examining forward and backward linkages through supply chains indicates that on average, selling to foreign-owned firms had a positive effect while buying from foreign owned firms had a negative effect on the average productivity of domestic firms. Finally, considering the absorptive capacity of domestic firms and allowing the spillover effects to differ depending on the origin of the parent companies, we find that the positive productivity spillovers come from supply chain linkages between domestic firms investing in R\&D and foreign affiliates of multinationals with headquarters based outside the EU.

JEL classification: F23, D22, O33.

Keywords :Foreign direct investment, productivity spillovers, absorptive capacity.

$* * * * * * * * * * * * * * * * * * * * * * * *$

\section{Effets induits de l'activité des multinationales sur la productivité des entreprises nationales en Irlande}

On dit parfois qu'outre ses effets directs sur la production et l'emploi, l'investissement direct étranger procure d'autres avantages économiques par des effets induits qui peuvent potentiellement améliorer les performances des entreprises nationales en termes de productivité. Or, les faits observés à cet égard sont généralement mitigés. Dans le présent document, nous utilisons des données microéconomiques sur des entreprises irlandaises de l'industrie et des services pour réexaminer et actualiser les analyses des effets induits intrasectoriels et infrarégionaux, puis nous prolongeons les travaux antérieurs en examinant si ces effets induits sont plus susceptibles d'intervenir via les liaisons dans les chaînes d'approvisionnement. Nous examinons plus avant la sensibilité de ces effets induits verticaux à d'autres modèles de chaînes d'approvisionnement. Dans l'ensemble, l'hypothèse d'un lien entre la présence de sociétés à capitaux étrangers et les performances des entreprises nationales n'est guère avérée, et nous observons une sensibilité considérable des résultats à tout changement de spécification. Nous constatons toutefois des variations intersectorielles importantes, avec une mise en évidence plus robuste d'effets induits par le canal intrasectoriel sur la productivité des entreprises dans les secteurs de services. L'examen des liaisons en amont et en aval dans les chaînes d'approvisionnement met en évidence certains effets négatifs des approvisionnements des entreprises nationales auprès de sociétés à capitaux étrangers et réciproquement, même si ces effets sont moindres pour les entreprises nationales qui investissent dans la R-D, ces investissements semblant accroître leur capacité d'absorption leur permettant de bénéficier d'effets induits sur leur productivité.

Classification JEL : F23, D22, O33.

Mots-clés : Investissement direct étranger, effets induits sur la productivité, capacité d'absorption. 


\section{Table of contents}

Productivity Spillovers from Multinational Activity to Local Firms in Ireland 4

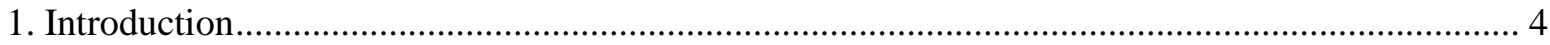

2. Data and Measurement of Productivity Spillover Channels ........................................................... 6

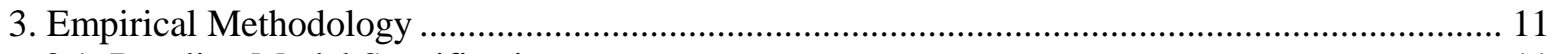

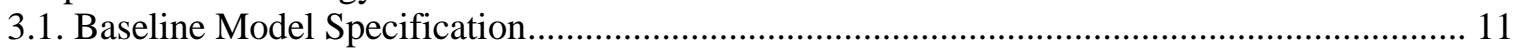

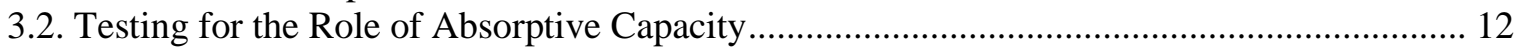

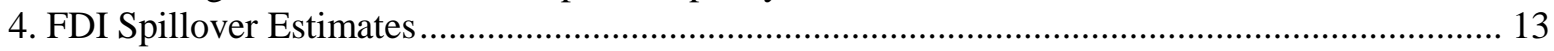

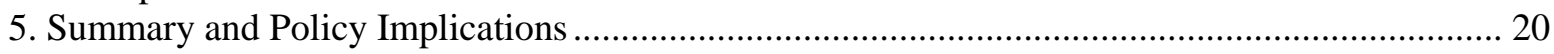

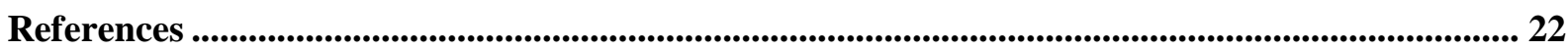

Annex A. Estimation of TFP at firm level ................................................................................. 25

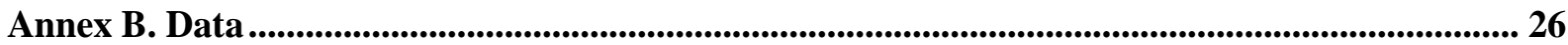

\section{Tables}

Table 1. Foreign ownership productivity premium, all firms, 2008-2014 ….................................... 9

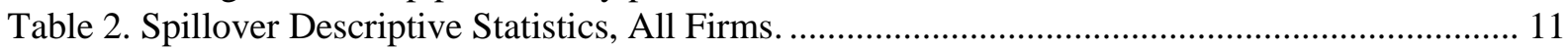

Table 3. Productivity spillovers from foreign affiliates to domestic firms, TFP Wooldridge, all

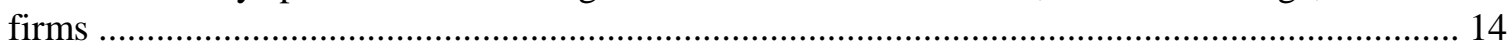

Table 4. Productivity spillovers from foreign affiliates to domestic firms, TFP Wooldridge estimates, EU and non-EU owned foreign affiliates, all firms ................................................. 16

Table 5. Productivity spillovers from foreign affiliates to domestic firms, All firms -The role of

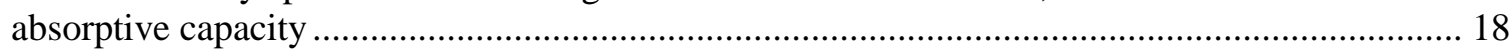

Table 6. Productivity spillovers from foreign affiliates to domestic firms, TFP Wooldridge, EU vs. non-EU owned foreign affiliates-the role of absorptive capacity, 2008-2014, all firms . 


\title{
Productivity Spillovers from Multinational Activity to Local Firms in Ireland
}

\author{
By Mattia Di Ubaldo, Martina Lawless and Iulia Siedschlag ${ }^{1}$
}

\section{Introduction}

1. The attraction of foreign direct investment has been a central plank of Irish economic policy for several decades and multinational enterprises make a considerable direct contribution to the Irish economy in the form of employment and output. In 2014, foreign-owned firms accounted for $24.3 \%$ of persons engaged and $52.1 \%$ of the gross value added in Ireland's non-financial business economy. ${ }^{2}$ In addition to the direct contribution of these firms, policy initiatives to attract multinational firms in countries across the world have frequently been further justified on the grounds that multinationals may also provide an indirect contribution in the form of learning opportunities or technology transfer to domestic firms. Spillovers of this type from multinational enterprises (MNEs) ${ }^{3}$ could potentially increase the productivity performance of domestic firms and may work through several different channels such as: demonstration effects, as domestic firms learn about new technologies and markets from the activities of multinationals; competition-induced innovation by local firms; knowledge spillovers via supply chain linkages between MNEs and local firms; and transfer of knowledge embedded in human capital through labour mobility. Conversely, negative spillovers could also arise if multinationals crowd out domestic firms through direct competition or diversion of resources.

2. The presence and extent of spillovers could be affected by many factors such as the characteristics of the MNEs, regional factors, technological gaps and the absorptive

\begin{abstract}
${ }^{1}$ Mattia Di Ubaldo - University of Sussex and the Economic and Social Research Institute (ESRI); Martina Lawless - the ESRI and Trinity College Dublin; Iulia Siedschlag (corresponding author: iulia.siedschlag@esri.ie) - the ESRI and Trinity College Dublin. This paper follows from research which provided background empirical analysis for the OECD Ireland Economic Survey 2018. This research is part of the joint ESRI and the Department of Finance/Revenue Commissioners Research Programme on the Macro-economy and Taxation. The views expressed in this paper are those of the authors and they should not be regarded as an official position of the Department of Finance or the Revenue Commissioners. This research uses statistical data from the Central Statistics Office (CSO) of Ireland. The permission for controlled access to confidential micro data sets has been granted in line with the Statistics Act, 1993. Results are based on analysis of strictly controlled Research Microdata Files provided by the Central Statistics Office (CSO). The CSO does not take any responsibility for the views expressed or the outputs generated from this research. The authors would like to thank Gerard Doolan, Andrew Murray, Barry Kelleher, Ben Berstock and Alan Corcoran from the CSO for valuable support with data access and clearance. We thank Brendan O'Connor, Javier Papa, and Luke Rehill from the Department of Finance for useful discussions and for sharing with us relevant output of the MultiProd project. We also thank two anonymous reviewers, Patrick Lenain, Ben Westmore, and Yosuke Jin from the OECD Economics Department and participants at the $2^{\text {nd }}$ Ministerial Summit on Productivity in San José for useful comments and suggestions. This paper also benefited from discussions with the members of the Steering Committee of the Research Programme on the Macro-economy and Taxation and participants at the Economic and Development Review Committee of the OECD. We thank Sarah Michelson (OECD Economics Department) for her excellent editorial support.
\end{abstract}

${ }^{2}$ Structural Business Statistics available from Ireland's Central Statistics Office. The corresponding figures for 2008 were $20.6 \%$ and $43.1 \%$, respectively.

${ }^{3}$ In this paper we use the terms MNEs, foreign affiliates and foreign-owned firms interchangeably. 
capacity of the domestic firms. A number of papers find that even though potential spillovers may be present, there are substantial differences across domestic firms in their ability to absorb any positive demonstration or technological benefits. For example, Girma, Görg and Pisu (2008) find that the export status of domestic firms is an important factor in this regard. Other papers have found that absorptive capacity is a crucial element in determining if local firms can benefit from the presence of MNEs (e.g Barrios et al. 2004; Barrios, Görg and Strobl, 2005; Girma and Görg, 2005 and 2007). In addition to the potential for spillovers to the productivity performance of domestic firms, the presence of multinationals has also been shown to have impacts on firm survival (Görg and Strobl, 2001) and export participation (Kneller and Pisu, 2007).

3. The question we examine in this paper is the extent to which there are productivity spillovers from multinationals to local firms in Ireland either because they are located in the same industry or in the same region, or through supply chain linkages. Internationally, these questions have been looked at across a range of countries and in general the evidence has been somewhat mixed, as can be found in meta-analyses over different periods and sets of countries that have been carried out by Görg and Strobl (2001), Havranek and Irsova (2011), McQuinn and Siedschlag (2013) and Demena and van Bergeijk (2017). Previous work on this issue in Ireland has focused on horizontal spillovers and considered manufacturing and service sectors separately (e.g. Ruane and Ugur 2005, and Haller 2014). Tests of horizontal spillovers use measures of the presence of MNEs within a sector or region to examine if this presence has any effect on the performance of domestic firms within the same sector or same region. The findings in this regard for Ireland have shown a mix of positive and negative effects but generally the estimates have been statistically insignificant.

4. While evidence on horizontal spillovers is very mixed, more recent research on vertical spillovers (Javorcik, 2004; Javorcik and Spatareanu, 2009) suggests that supply chain linkages are a better conduit for positive information and technology flows between multinationals and domestic firms. Measurement of linkages are a critical building block for the assessment of vertical spillovers. Barrios, Görg and Strobl (2011) argue that multinationals use more imported inputs than local inputs and this should be controlled for in the measure of sector links. In addition, they allow for the input sourcing behaviour of multinationals to be different from that of domestic firms and, in doing so, they find positive and statistically significant spillovers via backward linkages (purchases of inputs by foreign affiliates from local firms) and negative but statistically insignificant horizontal spillovers and via forward linkages (purchases of inputs by local firms from foreign affiliates). In further support of this argument, Javorcik and Spatareanu (2010) find evidence that the sourcing behaviour of multinationals can vary depending on how far away the home country is (as this can affect the share of intermediates obtained locally relative to those sourced from the home country or via intra-firm trade) and by whether trade agreements make local sourcing cheaper than imports that would be subject to tariffs. Consistent with this argument, they identify productivity spillovers on Romanian firms from US and Canadian MNEs but not from European-owned MNEs. Further evidence on the MNEs inputs sourcing behaviour is provided by Cadestin et al. (2018) who examine the sourcing structure of foreign affiliates and domestic firms in OECD countries. Their results indicate a large variation in the MNEs input sourcing behaviour across countries. In particular, and relevant for our analysis, they find that in small countries such as Belgium, Luxembourg and Ireland, foreign affiliates tend to source their inputs from abroad. In an extensive metaanalysis, Havranek and Irsova (2011) find that productivity spillovers are more likely to be observed from multinationals coming from more distant countries with a small productivity 
advantage over local firms. Morgenroth et al. (2015) find that productivity spillovers from multinationals to indigenous firms in Vietnam vary across provinces and sectors. Using information on direct technology transfers from foreign-owned to indigenous firms in Vietnam, Newman et al. (2015) find evidence on both direct and indirect productivity spillovers via supply chain linkages.

5. We expand on previous work done on this topic in Ireland in a number of ways, by looking at the impact on total factor productivity (TFP) rather than labour productivity and by using a richer set of measures of spillovers and of linkages across firms. The TFP estimates that we utilise are obtained as part of the OECD's MultiProd model using the Wooldridge (2009) methodology ${ }^{4}$ and applied to Irish firm level data by Department of Finance (2018). Given that the degree to which spillovers occur is affected by many factors such as the characteristics of the MNEs, regional factors, technological gaps and the absorptive capacity of the domestic firms, we include a rich set of firm characteristics to examine different potential channels for productivity spillovers to occur.

6. This paper first re-examines the horizontal channel to test if spillovers can be detected within sectors and within regions. Then, we build on the more recent international focus on vertical spillovers through supply chain linkages by testing for the existence of spillovers via forward and backward linkages (i.e. the supply chain channel). We use supply chain measures based on Barrios, Görg and Strobl (2011) allowing for the input sourcing behaviour of multinationals to differ across the location of the parent company.

7. Overall, we find limited evidence or a negative link between the presence of MNEs and the productivity of local firms in the same industry or the same region. Examining forward and backward linkages through supply chains indicates that on average, selling to foreign-owned firms had a positive effect while buying from foreign owned firms had a negative effect on the average productivity of local firms. Finally, considering the absorptive capacity of local firms and allowing the spillover effects to differ depending on the origin of the parent companies, we find that the positive productivity spillovers come from supply chain linkages between local firms investing in R\&D and foreign affiliates of multinationals based outside the EU.

8. Taken together, the evidence provided by this analysis suggests that the presence of foreign direct investment is not sufficient to generate benefits to indigenous firms but that enabling supply chain production linkages between indigenous and multinational firms has the potential to be beneficial for aggregate productivity. Such beneficial effects appear to be conditioned by the absorptive capacity of local firms and they are significant in particular in the case of linkages between local firms investing in R\&D and foreign affiliates owned by parent companies based in countries outside the EU.

9. The paper is structured as follows: Section 2 describes the data used in the empirical analysis and Section 3 outlines the methodological approach. Section 4 presents the results. Section 5 concludes.

\section{Data and Measurement of Productivity Spillover Channels}

10. This analysis primarily uses two data sets provided by Ireland's Central Statistics Office (CSO), one covering manufacturing firms - the Census of Industrial Production (CIP) - and the other covering services - the Annual Service Inquiry (ASI).

\footnotetext{
${ }^{4}$ An overview of the MultiProd model and details on measuring productivity at firm level are provided by Berlingieri et al. (2017).
} 
11. The CIP covers all manufacturing firms with three or more persons engaged. The information collected with the CIP survey includes location of ownership, turnover, employment and gross earnings, changes in capital assets, purchases of goods and services other than capital items. A more detailed questionnaire including information on changes in intangible assets, as well as exports and imports, is sent to firms with over 20 employees. The ASI covers all firms that have their main activity in the distribution and services sector. The ASI coverage has two components with a census carried out to cover all firms with over 20 employees and a stratified random sample for firms with less than 20 employees. As with the CIP, a more detailed questionnaire is sent to the larger firms (those with 20 or employees).

12. For the variables needed for this analysis, the broadest coverage for CIP and ASI microdata data is for the period 2008-2014. Combining the CIP and ASI sources, our analysis is based on an unbalanced panel of annual data over the seven year period, which results in 69,167 observations. In order to estimate total factor productivity for the firms in these two data sources, a number of important steps had to be taken. The variables were converted in a format compatible with the OECD guidelines on the estimation of productivity from the MultiProd model (Berlingieri et al., 2017) which also generated a separate analysis of productivity patterns and distributions (Department of Finance, 2018).

13. Of particular importance is that both original data sources include information on investments (changes in capital assets) but not on the firm capital stocks. As this is an important component of TFP estimation, capital stocks are estimated using the Perpetual Inventory Method (PIM) and utilising data from prior to the start of our main sample. In addition, some transformations of the investment series had to be made as a result of a reclassification of R\&D by the CSO from an expenditure item to an investment component from 2008. To ensure a harmonised treatment for our purposes, this necessitated adding the pre-2008 value of $R \& D$ spending by the enterprise to total capital additions and crosschecking for consistency against data from the Business Expenditure on R\&D (BERD) which was used to adjust some values for capitalised R\&D.

14. TFP estimates at firm level are obtained with the Wooldridge (2009) methodology which improves on previous semi-parametric methods. ${ }^{5}$ The main features of the Wooldridge methodology are described in Appendix A.

15. Detailed variables' definitions and data sources are given in Table B1 in the Appendix B. Summary statistics for firm characteristics for all firms and by ownership groups are shown in Tables B2 and B3. All monetary variables in current prices are transformed into constant 2005 US dollars in purchasing power parity using deflators available from the OECD STAN database.

16. Table 1 provides descriptive evidence on the foreign-ownership premia showing the estimated productivity gap between foreign-owned firms and domestic firms by size classes. ${ }^{6}$ The productivity of foreign-owned firms appears to be significantly higher relative to the productivity of indigenous firms within the same size class. The largest productivity gap is in the group of micro-firms (201.9\%) and the lowest in the group of the largest firms

\footnotetext{
${ }^{5}$ Van Beveren (2012) discusses in details advantages and limitations of existing methodologies to estimate TFP at firm level.

6 The foreign-ownership premia are obtained by regressing the log of firm-level productivity on indicator variables for EU-owned and non-EU owned affiliates.
} 
(15.9\%). With the exception of the group of micro firms, the foreign-ownership premia appear to be higher for non-EU owned affiliates relative to EU-owned affiliates. The productivity gap ${ }^{7}$ relative to domestic firms in the same size class is the highest for EU owned affiliates micro firms $(202.8 \%)$ and the lowest for medium-sized EU-owned affiliates $(9.8 \%)$. This descriptive evidence suggests that foreign affiliates are potential sources of productivity spillovers to the local firms.

${ }^{7}$ The productivity gap is obtained as [exp(coefficient)-1] ${ }^{*} 100$. 
Table 1. Foreign ownership productivity premium, all firms, 2008-2014

\begin{tabular}{|c|c|c|c|c|c|c|c|c|c|c|}
\hline & $\begin{array}{c}\text { Ln TFP } \\
\text { All }\end{array}$ & $\begin{array}{l}\text { Ln TFP } \\
\text { Micro }\end{array}$ & $\begin{array}{c}\text { Ln TFP } \\
\text { Small }\end{array}$ & $\begin{array}{c}\text { Ln TFP } \\
\text { Medium }\end{array}$ & $\begin{array}{c}\text { Ln TFP } \\
\text { Large }\end{array}$ & $\begin{array}{c}\text { Ln TFP } \\
\text { All }\end{array}$ & $\begin{array}{c}\text { Ln TFP } \\
\text { Micro }\end{array}$ & $\begin{array}{c}\text { Ln TFP } \\
\text { Small }\end{array}$ & $\begin{array}{l}\text { Ln TFP } \\
\text { Medium }\end{array}$ & $\begin{array}{l}\text { Ln TFP } \\
\text { Large }\end{array}$ \\
\hline Foreign-owned & $\begin{array}{c}0.262 * * * \\
(0.0187)\end{array}$ & $\begin{array}{c}1.105 * * * \\
(0.0520)\end{array}$ & $\begin{array}{c}0.399 * * * \\
(0.0235)\end{array}$ & $\begin{array}{c}0.184 * * * \\
(0.0266)\end{array}$ & $\begin{array}{l}0.148^{* *} \\
(0.0634)\end{array}$ & & & & & \\
\hline Foreign EU-owned & & & & & & $\begin{array}{c}0.297 * * * \\
(0.0247)\end{array}$ & $\begin{array}{c}1.108 * * * \\
(0.0649)\end{array}$ & $\begin{array}{c}0.301 * * * \\
(0.0313)\end{array}$ & $\begin{array}{c}0.0933 * * * \\
(0.0354)\end{array}$ & $\begin{array}{c}0.133 * \\
(0.0733)\end{array}$ \\
\hline Foreign non-EU owned & & & & & & $\begin{array}{c}0.226 * * * \\
(0.0246)\end{array}$ & $\begin{array}{l}1.101 * * * \\
(0.0844)\end{array}$ & $\begin{array}{c}0.507 * * * \\
(0.0329)\end{array}$ & $\begin{array}{c}0.257 * * * \\
(0.0327)\end{array}$ & $\begin{array}{c}0.166^{* *} \\
(0.0778)\end{array}$ \\
\hline Constant & & $\begin{array}{c}2.872 * * * \\
(0.0928) \\
\end{array}$ & $\begin{array}{c}2.848 * * * \\
(0.0701) \\
\end{array}$ & $\begin{array}{c}2.500^{* * * *} \\
(0.106) \\
\end{array}$ & $\begin{array}{c}1.855^{* * * *} \\
(0.437) \\
\end{array}$ & $\begin{array}{c}3.239^{* * * *} \\
(0.0558) \\
\end{array}$ & $\begin{array}{c}2.872 * * * * \\
(0.0928) \\
\end{array}$ & $\begin{array}{c}2.850^{* * * *} \\
(0.0701) \\
\end{array}$ & $\begin{array}{c}2.497 * * * \\
(0.106) \\
\end{array}$ & $\begin{array}{c}1.846 * * * \\
(0.438) \\
\end{array}$ \\
\hline$N$ & 68,878 & 26,485 & 29,901 & 10,249 & 2,243 & 68,878 & 26,485 & 29,901 & 10,249 & 2,243 \\
\hline
\end{tabular}

Notes: Estimates of TFP based on the Wooldridge (2009) obtained with the MultiProd model. All regressions include industry, region and time fixed effects. Standard errors in parentheses. $* \mathrm{p}<0.1, * * \mathrm{p}<0.05$, $* * * \mathrm{p}<0.01$. The definition of firm size classes is based on the number of employees as follows: micro: $1-9$ employees; small: 10-49 employees; medium: 50-249 employees; large: 250 and more employees.

Source: Authors' estimates using data from Ireland's Central Statistics Office (CSO). 
17. To estimate productivity spillovers from foreign affiliates to indigenous firms, we use the following measures for horizontal and vertical linkages:

- Horizontal intra-industry channel: $H O R_{j, t-k}=Y_{j, t-k}^{f} / Y_{j, t-k}$ : the share of foreign affiliates' employment ${ }^{8}$ in total employment in industry $\mathrm{j}$, at time $\mathrm{t}-\mathrm{k}$ ( $\mathrm{k}$ is the time lag $=0, \ldots, \mathrm{T})$

- Horizontal intra-region channel: $H_{O} R_{r, t-k}=Y_{r, t-k}^{f} / Y_{r, t-k}$ : the share of foreign affiliates' employment in total employment in region $\mathrm{r}$, at time $\mathrm{t}-\mathrm{k}$ ( $\mathrm{k}$ is the time lag $=0, \ldots, \mathrm{T})$

- Forward linkages:FOR $R_{j, t-k}=\sum_{l} \delta_{l j} H O R_{l, t-k}, l \neq j$; where $\delta_{l j}$ is the share of inputs of industry $\mathrm{j}$ purchased from industry $\mathrm{l}$; this measure for forward linkages captures the intermediate inputs available to indigenous firms in industry $j$ from foreign affiliates in upstream industries.

- Backward linkages: $B A C_{j, t-k}=\sum_{l} \gamma_{l j} H O R_{l, t-k}, l \neq j$; where $\gamma_{l j}$ is the share of output of industry $\mathrm{j}$ supplied to industry $\mathrm{l}$; this measure of backward linkages captures the indigenous firms' output in industry $j$ available to foreign affiliates in downstream industries.

18. Following Barrios, Görg, and Strobl (2011), we allow the input sourcing behaviour of MNEs to be specific to the home country of the parent company. To this purpose, in the calculation of the parameters $\delta_{l j}$ and $\gamma_{l j}$ we use the Input-Output table for each country of origin of the MNEs, taking the available information from the latest release of the World Input-Output (WIOT) database. ${ }^{9}$ To isolate better the supply chain linkages between indigenous firms and foreign affiliates, we exclude imports ${ }^{10}$ from the calculation of $\delta_{\mathrm{lj}}$ and $\gamma_{l j}$ as done in previous studies (see for example, Javorcik 2004; Barrios, Görg, and Strobl 2011; Jude 2016).

19. In addition to average spillover effects from all foreign-owned firms, we distinguish spillovers linked to affiliates owned by EU and by non-EU MNEs. To obtain these, we separate the employment shares in total industry/region employment by affiliates owned by EU and by non-EU MNEs, respectively.

20. Table 2 shows descriptive statistics for the measures of horizontal and vertical linkages used in the empirical analysis.

\footnotetext{
${ }^{8}$ In previous studies, foreign presence has been also measured as the share of foreign-owned firms in output or capital. In a meta-analysis of the productivity spillovers literature, Görg and Strobl (2001) find that estimates using employment or output shares appear to be similar, while using capital shares leads to lower estimates of productivity spillovers. Our choice for employment-based measures of foreign presence is motivated by the fact that these are less likely to be distorted by transfer pricing.

${ }^{9}$ The latest 2016 release includes input-output tables for 43 countries and a table for the rest of the world over the period 2000-2014. http://www.wiod.org/home. Details about using the WIOT data base are provided by Timmer et al. (2015).

${ }^{10}$ Hence only local production by Irish firms enter the calculation of the input or output shares.
} 
Table 2. Spillover Descriptive Statistics, All Firms.

\begin{tabular}{llll}
\hline & Obs. & Mean & Std \\
\hline Intra-industry & 81,511 & 0.318 & 0.173 \\
\hline Intra-region & 81,515 & 0.324 & 0.148 \\
\hline Forward link & 71,207 & 0.049 & 0.017 \\
\hline Backward link & 71,207 & 0.119 & 0.105 \\
\hline Intra-industry_EU & 69,232 & 0.128 & 0.075 \\
\hline Intra-industry_non_EU & 71,541 & 0.152 & 0.188 \\
\hline Intra-region_EU & 79,101 & 0.126 & 0.112 \\
\hline Intra-region_non_EU & 81,265 & 0.202 & 0.105 \\
\hline Forward link_EU & 71,207 & 0.027 & 0.012 \\
\hline Forward link_non_EU & 71,207 & 0.034 & 0.017 \\
\hline Backward link_EU & 71,207 & 0.038 & 0.026 \\
\hline Backward link_non_EU & 71,207 & 0.051 & 0.042 \\
\hline
\end{tabular}

Source: Authors' estimates using data from Ireland's Central Statistics Office (CSO) and the World InputOutput Tables (WIOT).

\section{Empirical Methodology}

21. This section outlines the methodology used to estimate the extent of productivity spillovers from multinationals on Irish-owned firms. In order to accurately capture any productivity effect, the first stage of the overall estimation procedure is to estimate the TFP of the domestic firms. The estimates for TFP are obtained with the OECD MultiProd model using the Wooldridge (2009) methodology (for details see Berlingieri et al., 2017 and Appendix A). ${ }^{11}$ In the second stage, we use these TFP estimates as the dependent variable and examine to what extent, if any, they were affected by measures of exposure to multinational activity, in either the same sector, region as the domestic firm or via supply chain linkages.

\subsection{Baseline Model Specification}

22. The baseline model specification to estimate productivity spillovers from foreignowned firms to domestic firms is as follows:

$$
\begin{aligned}
\ln T F P_{i j r t}^{d}=\beta_{0} & +\beta_{1} H_{O O R_{j, t-k}}+\beta_{2} H_{O O R_{r, t-k}}+\beta_{3} F O R_{j, t-k}+\beta_{4} B A C_{j, t-k} \\
& +\beta_{5} \Delta S A L E S_{j t}+\beta_{6} H H I_{j t}+\sum_{q=1}^{4} \beta_{q} Z_{i j r t}+\mu_{i}+\lambda_{j}+\rho_{r}+\tau_{t}+\varepsilon_{i j r t}
\end{aligned}
$$

${ }^{11}$ We thank Brendan O'Connor, Javier Papa, and Luke Rehill from the Department of Finance for sharing with us these estimates. 
23. The dependent variable, $T F P_{i j r t}^{d}$ is the total factor productivity of domestic firm $i$, in industry $j$, region $r$, at time $t$.

24. $Z_{i j r t}^{d}$ captures a range of firm characteristics for domestic firms. These include the size class of the firm ${ }^{12}$ as well as its import and export status (both included as categorical variables). To control for the average absorptive capacity of the firm to benefit from spillovers, we also include a categorical variable which is equal to one for firms with $R \& D$ investment and zero otherwise, and a proxy for human capital (wages per employee, taken in $\log s) .{ }^{13}$

25. At the industry level, $\Delta$ Sales $_{j t}$ measures sales growth to control for industryspecific demand shocks which might affect the measures of spillovers. $H H I_{j t}$ is the Herfindahl-Hirschman index in industry $j$ at time $t$ which controls for within industry competition. For each industry $\mathrm{j}$, the $H H I$ index is computed as follows:

26.

$$
H H I_{j t}=\sum_{i}^{N} s_{i j t}^{2}
$$

27. $s_{i j t}^{2}$ denotes the market share of firm $\mathrm{i}$ at time $\mathrm{t}$ in industry $\mathrm{j}$.

28. Firm, industry, region and time fixed effects are included in all specifications to control for unobserved confounding factors. Further endogeneity concerns could arise from the fact that foreign firms may be systematically attracted to particular industries or regions due to their productivity performance. To address this concern, in our approach, we use lagged variables for each of the spillover channel. ${ }^{14}$ Self-selection of foreign firms into high productivity industries is also avoided by restricting the analyzed sample to domestic firms. ${ }^{15}$ Finally, all standard errors are clustered at the industry-year level.

\subsection{Testing for the Role of Absorptive Capacity}

29. To test explicitly for the role of firms' absorptive capacity in capturing and internalizing productivity spillovers, we augment the model in Eq. (1) with a binary R\&D indicator ${ }^{16}$ interacted with the spillover variables. The augmented econometric model is as follows:

\footnotetext{
${ }^{12}$ Size is controlled for using the following four size classes: micro (1-9 employees); small (10-49 employees); medium (50-249 employees); large (250 and more employees). The reference category in regressions is micro firms.

13 These controls simply avoid the omitted variable bias arising from the fact that R\&D investment and human capital can affect both firm productivity and the spillover effect, confounding the main result we are interested in. Later, in eq. (3) we test separately for the additional spillover effect due to being an R\&D investor, modelling explicitly the role of absorptive capacity.

14 This approach has been used among others by Haskel, Pereira and Slaughter (2007), and Barrios, Görg, and Strobl (2011).

${ }^{15}$ See for example, Javorcik and Spatareanu (2008) and Barrios, Görg, and Strobl (2011).

${ }^{16}$ This variable takes the value one for firms with investment in R\&D and zero otherwise.
} 


$$
\begin{aligned}
& \operatorname{lnTFP} P_{i j r t}^{d}=\beta_{0}+\beta_{1} H_{O O R_{j, t-k}}+\beta_{2} H O R_{r, t-k}+\beta_{3} F O R_{j, t-k}+\beta_{4} B A C_{j, t-k}+\beta_{5} R D_{i j r t} * \\
& H O R_{j, t-k}+\beta_{6} R D_{i j r t} * H O R_{r, t-k}+\beta_{7} R D_{i j r t} * F O R_{j, t-k}+\beta_{8} R D_{i j r t} * B A C_{j, t-k}+ \\
& \beta_{9} Z_{i j r t}^{d}+\beta_{10} \Delta S A L E S_{j t}+\beta_{11} H H I_{j t}+\mu_{i}+\lambda_{j}+\rho_{r}+\tau_{t}+\varepsilon_{i j r t}
\end{aligned}
$$

30. On the basis of previous evidence (see for example Griffith et al. 2004), we expect positive values for the parameters, $\beta_{5}, \beta_{6}, \beta_{7}, \beta_{8}$ indicating larger productivity spillovers for domestic firms investing in $R \& D$ relative to those without investment in $R \& D$.

\section{FDI Spillover Estimates}

31. This section presents our estimates of the extent to which the productivity of Irishowned firms is affected by the presence of MNEs and if these effects differ across the various channels through which linkages could operate - intra-industry, intra-region, forward and backward supply connections. We also examine the extent to which spillover effects might accumulate or erode over time, by estimating the models with a number of different lag lengths (one to three years) when assessing the extent of the potential spillovers.

32. As discussed in the previous sections, an important factor in the measurement of the linkages along the supply chain relates to the choice of input-output tables used. We adopt the method of Barrios, Görg and Strobl (2011) to estimate the impact of the supply linkages using a separate input-output table for the home country of each multinational. This allows the sourcing behaviour of MNEs to vary by nationality, rather than restricting them to the same pattern of purchasing and sales as domestic Irish firms.

33. We further distinguish between spillover strength coming from different types of multinationals, specifically depending on whether they have EU or non-EU ultimate owners. Our final set of specifications examine if the absorptive capacity of the domestic firm, proxied by its R\&D activity, condition the effects of engagement with multinationals on its performance.

34. Table 3 presents the baseline estimates, which examine the effects of the various potential spillover channels on the productivity (TFP) of all domestic firms, together with how sensitive the effects are to using different lags for the spillover measures. Beginning with intra-industry spillovers, arising from the presence ${ }^{17}$ of MNEs within the same sector, we find a negative effect when the one-year lagged spillover measure is used. The coefficient in column 1 for intra-industry horizontal spillovers implies that 10 percentage points increase in the presence of foreign affiliates in the same sector is associated with a 9 per cent productivity decrease of domestic firms. The negative effect becomes insignificant with a two years lag and turns positive albeit not significantly so when the spillover is lagged by three years. The next key finding is that there is very limited evidence of any effect of MNEs presence on the productivity of Irish-owned firms active in the same region. The coefficients on horizontal regional spillovers with one and three year lags are indistinguishable from zero, although there is a slight negative and weakly significant effect when a two year lag is used.

35. We find more evidence of effects on domestic productivity coming from supply linkage channels. We find that, on average, domestic firms experience a negative

\footnotetext{
${ }^{17}$ Measured by the employment share of foreign firms.
} 
productivity spillover coming through the channel of supplies to domestic firms by foreignowned firms. The forward linkages coefficient suggests that domestic firms in industries which are more exposed to MNEs activity upstream, through a combination of a stronger input-output link and a larger MNEs presence in the input producing industries, tend to have lower productivity levels than firms relying less on inputs produced in MNEs dominated sectors. Merlevede and Schoors (2009) suggest that forward spillovers can be negative either if the inputs from MNEs are more expensive than domestic inputs or if the purchased inputs are less adapted to the requirements of the domestic purchasers, which could weigh against the expected higher technological content of goods produced by multinationals.

Table 3. Productivity spillovers from foreign affiliates to domestic firms, TFP Wooldridge, all firms

\begin{tabular}{|l|c|c|c|}
\hline Lag & One year & Two year & Three year \\
\hline Intra-Industry & $-0.937^{* * *}$ & -0.177 & 0.146 \\
\hline Intra-Region & $(0.279)$ & $(0.231)$ & $(0.258)$ \\
\hline & 0.0746 & $-0.225^{*}$ & -0.258 \\
\hline Forward Link & $(0.111)$ & $(0.127)$ & $(0.189)$ \\
\hline & $-9.137^{* * *}$ & $-12.440^{* * *}$ & $-9.580^{* * *}$ \\
\hline Backward Link & $(2.724)$ & $(3.989)$ & $(2.223)$ \\
\hline & $5.071^{* *}$ & $4.368^{* * *}$ & $1.956^{*}$ \\
\hline Industry sales growth & $(2.230)$ & $(1.414)$ & $(0.989)$ \\
\hline & $0.113^{* *}$ & -0.004 & $0.115 * * *$ \\
\hline HHI & $(0.051)$ & $(0.052)$ & $(0.030)$ \\
\hline & -0.315 & -0.109 & -0.094 \\
\hline R\&D investor & $(0.369)$ & $(0.138)$ & $(0.073)$ \\
\hline & 0.005 & -0.012 & -0.002 \\
\hline Exporter & $(0.012)$ & $(0.018)$ & $(0.020)$ \\
\hline & 0.002 & -0.027 & -0.032 \\
\hline Importer & $(0.017)$ & $(0.022)$ & $(0.026)$ \\
\hline & -0.015 & $-0.028 *$ & -0.008 \\
\hline Ln wage per employee & $(0.012)$ & $(0.015)$ & $(0.016)$ \\
\hline & $0.052^{* *}$ & 0.032 & -0.002 \\
\hline Constant & $(0.023)$ & $(0.025)$ & $(0.037)$ \\
\hline N & $2.143^{* * *}$ & $2.732^{* * *}$ & $3.040^{* * *}$ \\
\hline & $(0.326)$ & $10.322)$ & $(0.385)$ \\
\hline & 20,740 & 8,751 \\
\hline
\end{tabular}

Notes: Estimates of TFP based on the Wooldridge (2009) obtained with the MultiProd model. All regressions include industry, region and time fixed effects. Standard errors clustered by industry-year in parentheses. * $\mathrm{p}<0.1, * * \mathrm{p}<0.05, * * * \mathrm{p}<0.01$

Source: Authors' estimates using data from Ireland's Central Statistics Office (CSO).

36. In contrast, we find a positive effect of backward linkages on the productivity of domestic firms: a larger MNE presence downstream of domestic firms appears to have the opposite effect than a larger presence upstream. This implies that selling to foreign-owned firms has more of a technology transfer effect than buying from them. Taking the Merlevede and Schoors logic to this result could suggest that selling to multinationals requires domestic firms to adapt and upgrade their products in a way that is beneficial for their overall efficiency. A one percentage point increase in the backward spillover measure 
(column 1) is associated with a five per cent increase in the productivity of domestic firms, with this effect persisting at longer lag lengths although with a declining strength over time.

37. Turning to some of the additional control variables, we find very few statistically significant coefficients, with the exception of industry sales growth, which presents a reasonably strong and positive effect at the one and three year horizons. The lack of significance in the remaining coefficients is not surprising given the use of firm, industry, region and time fixed effects, in each specification. The firm fixed effects, in particular, constrain the estimated effects to arise from time variation within firm. This implies, for instance, that the exporter/importer effect is identified from firms switching into and out of exporting/importing over time, which is not observed very often, given the persistent status of these activities (for an overview of this evidence, see Love and Roper, 2015). We can explain similarly the lack of significance of R\&D investment on productivity. ${ }^{18}$

38. The next set of results, presented in Table 4, looks at whether spillover effects to domestic firms might differ (either in direction or magnitude) depending on the ownership location of the multinational. To investigate this point, we separate MNEs into two broad groups - those owned by EU parent firms and those with non-EU parents. As access to the EU market is one of the key attractions of locating in Ireland for non-EU firms, their effect may differ in many regards relative to EU-owned MNEs which chose to locate an affiliate in Ireland. ${ }^{19}$

39. The results in Table 4 show a range of specifications where spillovers from EUowned multinationals are found to have negative impacts on the productivity of domestic Irish firms. This is particularly the case for intra-industry links and for forward linkages, which confirms the aggregate result presented in Table 3 . The evidence on the effects of backward linkages between EU-owned multinationals and domestic firms is mixed, with different effects found for each lag length. The presence of non-EU firms generally has no statistically significant effect on the productivity of Irish-owned firms, with the exception of one positive effect at a two year lag from the intra-industry measure.

\footnotetext{
${ }^{18}$ We will see in later specifications, however, that investing in $R \& D$ can be a factor in the ability to benefit from linkages with multinationals when it is interacted with the spillover channels, although this effect varies considerably across models.

${ }^{19}$ This argument follows from evidence provided by Davies, Siedschlag and Studnicka 2016.
} 
Table 4. Productivity spillovers from foreign affiliates to domestic firms, TFP Wooldridge estimates, EU and non-EU owned foreign affiliates, all firms

\begin{tabular}{|c|c|c|c|}
\hline Lag & One-year & Two-year & Three-year \\
\hline \multirow{2}{*}{ Intra- Industry_EU } & $-1.198 * * *$ & $-0.841 * * *$ & -0.314 \\
\hline & $(0.360)$ & $(0.298)$ & $(0.257)$ \\
\hline \multirow[t]{2}{*}{ Intra-Industry_non_EU } & 0.226 & $0.819^{* *}$ & 0.016 \\
\hline & $(0.226)$ & $(0.374)$ & $(0.208)$ \\
\hline \multirow[t]{2}{*}{ Intra-Region_EU } & 0.255 & 0.052 & -0.301 \\
\hline & $(0.188)$ & $(0.194)$ & $(0.205)$ \\
\hline \multirow[t]{2}{*}{ Intra-Region_non_EU } & 0.130 & -0.181 & -0.182 \\
\hline & $(0.124)$ & $(0.156)$ & $(0.230)$ \\
\hline \multirow[t]{2}{*}{ Forward Link_EU } & $-11.780 * * *$ & $-12.810 * * *$ & $-5.316^{* *}$ \\
\hline & $(2.714)$ & $(4.684)$ & $(2.293)$ \\
\hline \multirow[t]{2}{*}{ Forward Link_non_EU } & 7.641 & -0.776 & -2.459 \\
\hline & $(6.204)$ & $(5.170)$ & $(3.663)$ \\
\hline \multirow[t]{2}{*}{ Backward Link_EU } & $-3.449^{*}$ & 1.313 & $3.856^{* * * *}$ \\
\hline & $(1.762)$ & (1.995) & $(1.370)$ \\
\hline \multirow[t]{2}{*}{ Backward Link_non_EU } & -1.268 & 2.961 & 1.413 \\
\hline & $(2.773)$ & $(2.044)$ & $(2.131)$ \\
\hline \multirow[t]{2}{*}{ Industry sales growth } & 0.037 & $-0.111 * *$ & $0.096^{* *}$ \\
\hline & $(0.046)$ & $(0.047)$ & $(0.039)$ \\
\hline \multirow[t]{2}{*}{ HHI } & -0.261 & -0.024 & 0.088 \\
\hline & $(0.289)$ & $(0.144)$ & $(0.053)$ \\
\hline \multirow[t]{2}{*}{ R\&D investor } & 0.003 & -0.006 & -0.001 \\
\hline & $(0.012)$ & $(0.017)$ & $(0.018)$ \\
\hline \multirow[t]{2}{*}{ Exporter } & 0.005 & -0.030 & -0.037 \\
\hline & $(0.018)$ & $(0.024)$ & $(0.024)$ \\
\hline \multirow[t]{2}{*}{ Importer } & -0.011 & $-0.030^{*}$ & -0.004 \\
\hline & $(0.013)$ & $(0.016)$ & $(0.017)$ \\
\hline \multirow[t]{2}{*}{ Ln wage per employee } & $0.055^{* *}$ & 0.038 & 0.001 \\
\hline & $(0.026)$ & $(0.028)$ & $(0.042)$ \\
\hline \multirow[t]{2}{*}{ Constant } & $2.316 * * *$ & $2.583 * * *$ & $2.867 * * *$ \\
\hline & $(0.374)$ & $(0.371)$ & $(0.422)$ \\
\hline$N$ & 18,911 & 11,095 & 7,954 \\
\hline
\end{tabular}

Notes: Estimates of TFP based on the Wooldridge (2009) obtained with the MultiProd model. All regressions include industry, region and time fixed effects. Standard errors clustered by industry-year in parentheses. * $\mathrm{p}<0.1, * * \mathrm{p}<0.05, * * * \mathrm{p}<0.01$.

Source: Authors' estimates using data from Ireland's Central Statistics Office (CSO).

40. Some of the variation in effects found in these initial specifications may be due to differing absorptive capacities of the domestic firms, leading to a heterogeneous effect of the various spillovers. This could come about if the extent to which spillovers affect firm productivity depends not just on exposure of domestic firms to more advanced technologies or business processes in multinationals, but also on the capacity of the domestic firm to 
adopt them. Previous studies (see for example Blalock and Gertler 2008; Jude 2016) suggest that accounting for absorptive capacity is a crucial factor in understanding how technology may be transferred. One potential proxy for this absorptive capacity of domestic firms is their engagement in R\&D activity. In the remaining specifications, we investigate the extent to which this affects our previous results. In order to do this, we interact a categorical variable which captures whether or not domestic firms invest in R\&D with the different spillover channels. This interaction reveals whether the effects of MNEs' presence on domestic firms differs depending on their absorptive capacity. Table 5 presents the results from pooling all multinationals together; Table 6 examines if the effects differ by EU and non-EU multinationals.

41. Allowing the spillover effect to differ depending on the R\&D activity of domestic firms gives a somewhat clearer pattern of results, with the main effects coming through strongly for supply chain links. Forward linkages show a consistently negative impact on domestic firms' productivity, whereas a positive impact is estimated for backward linkages. This latter one is particularly evident in the one-year lag specification, where a 10 per cent increase in the extent of linkages would raise domestic TFP by 51 per cent. The strength of the effects diminishes over time but remains statistically significant up to the three-year lag specification.

42. The final set of results, Table 6, looks at the effect of multinational ownership (EU vs non-EU) in interaction with the R\&D involvement of domestic firms, to drill further into the mechanisms at play. Table 6 shows, again, that the direction of linkage is crucial, with forward linkages being found to have negative effects on domestic firms' TFP, especially when arising from EU MNEs for non-R\&D investors. Dividing MNEs into EU and nonEU groups shows that the primary positive spillover channel is from non-EU multinationals to $R \& D$ active domestic firms, although the effect vanishes when two and three-years lagged spillovers measures are exploited. Taken together, the findings that negative forward spillovers affect non-R\&D active firms and positive backward spillovers mainly affect $R \& D$ active firms, highlight the importance of absorptive capacity. This can be a crucial factor in determining the operation of spillover effects and which domestic firms are most likely to benefit. 
Table 5. Productivity spillovers from foreign affiliates to domestic firms, All firms -The role of absorptive capacity

\begin{tabular}{|c|c|c|c|}
\hline Lag & One-year & Two- year & Three-year \\
\hline \multicolumn{4}{|l|}{ Intra-Industry } \\
\hline & $-0.925 * * *$ & -0.182 & 0.147 \\
\hline & $(0.280)$ & $(0.230)$ & $(0.259)$ \\
\hline \multirow[t]{2}{*}{ Intra-Region } & 0.058 & $-0.229 *$ & -0.240 \\
\hline & $(0.112)$ & $(0.127)$ & $(0.187)$ \\
\hline \multirow[t]{2}{*}{ Intra-Industry*RD } & -0.050 & 0.041 & -0.008 \\
\hline & $(0.076)$ & $(0.100)$ & $(0.122)$ \\
\hline \multirow[t]{2}{*}{ Intra-Region*RD } & 0.069 & 0.025 & -0.101 \\
\hline & $(0.081)$ & $(0.121)$ & $(0.119)$ \\
\hline Forward Link & $\begin{array}{c}-\mathbf{9 . 0 8 4} * * * \\
(2.717)\end{array}$ & $\begin{array}{c}-\mathbf{1 2 . 5 2 0} * * * * \\
(3.949)\end{array}$ & $\begin{array}{c}-\mathbf{9 . 6 2 5} * * * \\
(2.227)\end{array}$ \\
\hline \multirow[t]{2}{*}{ Forward Link*RD } & 0.118 & 0.969 & -0.619 \\
\hline & $(0.633)$ & $(0.895)$ & $(1.071)$ \\
\hline \multirow[t]{2}{*}{ Backward Link } & $5.114 * *$ & $4.375 * * *$ & $1.950 *$ \\
\hline & (2.238) & $(1.424)$ & $(0.995)$ \\
\hline Backward Link*RD & $\begin{array}{l}-0.125 \\
(0.108)\end{array}$ & $\begin{array}{c}0.090 \\
(0.165)\end{array}$ & $\begin{array}{l}-0.124 \\
(0.219)\end{array}$ \\
\hline \multirow[t]{2}{*}{ Industry sales growth } & $0.113^{* *}$ & -0.006 & $0.117 * * *$ \\
\hline & $(0.051)$ & $(0.052)$ & $(0.030)$ \\
\hline \multirow[t]{2}{*}{ HHI } & -0.314 & -0.107 & -0.094 \\
\hline & $(0.369)$ & $(0.138)$ & $(0.073)$ \\
\hline \multirow[t]{2}{*}{ R\&D investor } & 0.008 & -0.095 & 0.075 \\
\hline & $(0.056)$ & $(0.080)$ & $(0.103)$ \\
\hline \multirow[t]{2}{*}{ Importer } & -0.015 & $-0.028 *$ & -0.008 \\
\hline & $(0.012)$ & $(0.015)$ & $(0.017)$ \\
\hline \multirow[t]{2}{*}{ Ln wage per employee } & $0.052 * *$ & 0.032 & -0.001 \\
\hline & $(0.023)$ & $(0.025)$ & (0.037) \\
\hline \multirow[t]{3}{*}{ Constant } & & & \\
\hline & $2.140 * * *$ & $2.742 * * *$ & $3.029 * * *$ \\
\hline & $(0.326)$ & $(0.323)$ & $(0.386)$ \\
\hline$N$ & 20,740 & 12,259 & 8,751 \\
\hline
\end{tabular}

Notes: Estimates of TFP based on the Wooldridge (2009) obtained with the MultiProd model. All regressions include industry, region and time fixed effects. Standard errors clustered by industry-year in parentheses. * $\mathrm{p}<0.1, * * \mathrm{p}<0.05, * * * \mathrm{p}<0.01$.

Source: Authors' estimates using data from Ireland's Central Statistics Office (CSO). 
Table 6. Productivity spillovers from foreign affiliates to domestic firms, TFP Wooldridge, EU vs. non-EU owned foreign affiliates-the role of absorptive capacity, 2008-2014, all firms

\begin{tabular}{|c|c|c|c|}
\hline Lag & One year & Two-year & Three-year \\
\hline \multirow[t]{2}{*}{ Horizontal_Industry_EU } & $-1.213 * * *$ & $-0.879 * * *$ & $-0.654 * *$ \\
\hline & $(0.372)$ & $(0.332)$ & $(0.254)$ \\
\hline \multirow[t]{2}{*}{ Horizontal_Industry_non_EU } & 0.244 & $0.867 * *$ & 0.184 \\
\hline & $(0.222)$ & $(0.378)$ & $(0.181)$ \\
\hline \multirow[t]{2}{*}{ Horizontal_Region_EU } & 0.223 & 0.068 & -0.319 \\
\hline & $(0.191)$ & $(0.203)$ & $(0.201)$ \\
\hline \multirow[t]{2}{*}{ Horizontal_Region_non_EU } & 0.103 & -0.182 & -0.156 \\
\hline & $(0.124)$ & $(0.152)$ & $(0.241)$ \\
\hline \multirow[t]{2}{*}{ Forward Links_EU } & $-11.540 * * *$ & $-12.980 * * *$ & $-5.051 * *$ \\
\hline & $(2.723)$ & $(4.578)$ & $(2.248)$ \\
\hline \multirow[t]{2}{*}{ Forward Link_non_EU } & 7.234 & -0.420 & -2.742 \\
\hline & $(6.178)$ & $(5.175)$ & $(3.405)$ \\
\hline \multirow{2}{*}{ Backward Link_EU } & $-3.031 *$ & 1.244 & $3.702 * * *$ \\
\hline & $(1.785)$ & $(1.997)$ & $(1.399)$ \\
\hline \multirow[t]{2}{*}{ Backward Link_non_EU } & -1.522 & 2.935 & 0.901 \\
\hline & $(2.786)$ & $(2.058)$ & $(1.934)$ \\
\hline \multirow[t]{2}{*}{ Horizontal_Industry_EU*RD } & -0.0392 & 0.153 & $1.100 * * *$ \\
\hline & $(0.202)$ & $(0.278)$ & $(0.354)$ \\
\hline \multirow[t]{2}{*}{ Horizontal_Industry_non_EU*RD } & -0.0716 & -0.063 & $-0.199 * * *$ \\
\hline & $(0.0711)$ & $(0.086)$ & $(0.075)$ \\
\hline \multirow[t]{2}{*}{ Horizontal_Region_EU*RD } & 0.118 & 0.000542 & 0.0252 \\
\hline & $(0.120)$ & $(0.160)$ & $(0.153)$ \\
\hline \multirow[t]{2}{*}{ Horizontal_Region_non_EU*RD } & 0.0681 & 0.00556 & -0.0943 \\
\hline & $(0.094)$ & $(0.170)$ & $(0.189)$ \\
\hline \multirow[t]{2}{*}{ Forward Link_EU*RD } & $-2.690^{*}$ & 2.469 & 1.398 \\
\hline & $(1.510)$ & $(2.340)$ & $(2.180)$ \\
\hline \multirow[t]{2}{*}{ Forward Link_non_EU*RD } & $1.561 *$ & 0.184 & 0.607 \\
\hline & $(0.863)$ & $(1.154)$ & $(1.306)$ \\
\hline \multirow[t]{2}{*}{ Backward Link_EU*RD } & $-2.478 * * *$ & 0.298 & 0.0354 \\
\hline & $(0.820)$ & $(1.256)$ & $(1.259)$ \\
\hline \multirow[t]{2}{*}{ Backward Link_non_EU*RD } & $1.370 * * *$ & 0.292 & -0.576 \\
\hline & $(0.485)$ & $(0.680)$ & $(0.613)$ \\
\hline \multirow[t]{2}{*}{ Industry sales growth } & 0.0360 & $-0.114 * *$ & $0.0770 * *$ \\
\hline & $(0.046)$ & $(0.049)$ & $(0.035)$ \\
\hline \multirow[t]{2}{*}{ HHI } & -0.275 & -0.0207 & $0.0943 *$ \\
\hline & $(0.290)$ & $(0.144)$ & $(0.051)$ \\
\hline \multirow[t]{2}{*}{ R\&D investor } & 0.0336 & -0.113 & -0.108 \\
\hline & $(0.062)$ & $(0.088)$ & $(0.100)$ \\
\hline Exporter & 0.00368 & -0.0309 & -0.0350 \\
\hline
\end{tabular}




\begin{tabular}{|l|c|c|c|}
\hline & $(0.017)$ & $(0.024)$ & $(0.024)$ \\
\hline Importer & -0.0129 & $-0.0305^{*}$ & -0.00317 \\
\hline Ln wage per employee & $(0.013)$ & $(0.016)$ & $(0.017)$ \\
\hline Constant & $0.0551 * *$ & 0.0371 & 0.003 \\
\hline & $(0.0258)$ & $(0.0284)$ & $(0.043)$ \\
\hline & $2.326 * * *$ & $2.581 * * *$ & $2.891 * * *$ \\
\hline
\end{tabular}

Notes: Estimates of TFP based on the Wooldridge (2009) obtained with the MultiProd model. All regressions include industry, region and time fixed effects. Standard errors clustered by industry-year in parentheses. * $\mathrm{p}<0.1, * * \mathrm{p}<0.05, * * * \mathrm{p}<0.01$.

Source: Authors' estimates using data from Ireland's Central Statistics Office (CSO).

\section{Summary and Policy Implications}

43. This paper re-examines the question of whether and to what extent multinationals can affect the performance of domestic firms. Using productivity estimates for Irish-owned firms we find that, on average, there is a negative link between the presence of foreignowned firms in the same industry and the performance of domestic firms. We find no evidence of intra-region productivity spillovers.

44. While the presence of multinationals in an industry or region has been the traditional method to capture spillovers to domestic firms, supply chain links between domestic and foreign-owned firms could be a more important source of technology transfer. We therefore examine if there is any evidence of productivity spillovers to domestic firms from forward and backward linkages with foreign-owned affiliates. Looking across all firms, the productivity of domestic firms in upstream industries is positively linked to supplies to foreign owned firms. This result suggests that supplying inputs to multinationals is an important channel for knowledge and technology transfers. In contrast, the productivity of domestic firms in downstream industries is negatively linked to purchases from foreign-owned firms.

45. In order to decompose the potential learning channels further, we allow for different effects for affiliates owned by EU and non-EU multinationals. In doing this, we find that the productivity of domestic firms is negatively linked to the presence of EU-based multinationals in the same industry and positively linked to the presence of non-EU based multinationals in the same industry. Examining supply chain linkages, we find that buying from and supplying inputs to foreign affiliates of EU-based multinationals are associated with decreases of the average productivity of domestic firms. Supply chain linkages with non-EU multinationals do not affect significantly the average productivity of domestic firms.

46. Finally, this paper shows that R\&D investment, standing for the absorptive capacity of firms, can be an important conduit of productivity spillovers. Without distinguishing between EU and non-EU MNEs, investing in R\&D does not seem to make a difference to domestic firms in absorbing positive and/or negative spillovers. When a distinction between EU and non-EU MNEs is made, domestic firms which invest in R\&D appear to be more successful in internalising spillovers from supplying foreign-owned firms with non-EU headquarters while domestic firms non-investing in $R \& D$ appear to be those mostly penalised from buying inputs from EU based MNEs. 
47. The evidence provided by this analysis indicates that attracting foreign direct investment is not sufficient to generate benefits to indigenous firms via involuntary knowledge spillovers and demonstration effects. Since productivity spillovers are not automatic, enhancing the absorptive capacity of indigenous firms is key in order to ensure they can benefit from advanced knowledge and technologies associated with multinational firms. 


\section{References}

Ackerberg, Daniel, Kevin Caves, and Garth Frazer (2015), "Identification properties of recent production function estimators", Econometrica 83(6), 2411-2451.

Berlingieri, Giuseppe, Patrick Blanchenay, Sara Calligaris and Chiara Criscuolo (2017), "The MultiProd project: A comprehensive overview", OECD Science, Technology and Industry Working Papers, 2017/04, OECD Publishing, Paris.

Barrios, Salvador, Sophia Dimelis, Helen Louri and Eric Strobl (2004), "Efficiency spillovers from foreign direct investment in the EU periphery: a comparative study of Greece, Ireland and Spain", Review of World Economics, Vol. 140, No.4, pages 688-705.

Barrios, Salvador, Holger Görg and Eric Strobl (2005), "Foreign direct investment competition and industrial development in the host country", European Economic Review Vol. 49 pages 1761-1784.

Barrios, Salvador, Holger Görg and Eric Strobl (2011), "Spillovers through backward linkages from multinationals: Measurement matters!" in European Economic Review, Vol.55, pages 862-875.

Blalock, Garrick, and Paul J. Gertler (2009), "How firm capabilities affect who benefits from foreign technology", Journal of Development Economics, 90(2), pages 192-199.

Cadestin, Charles, Koen De Backer, Isabelle Desnoyers-James, Sébastien Miroudot, Ming Ye, and Davide Rigo (2018), "Multinational enterprises and global value chains: New Insights on the trade-investment nexus", OECD Science, Technology and Industry Working Papers, No. 2018/05, OECD Publishing, Paris, https://doi.org/10.1787/194ddb63-en.

Davies, Ronald B., Iulia Siedschlag and Zuzanna Studnicka (2016), "Corporate taxation and foreign direct investment in EU Countries: Policy implications for Ireland”, ESRI Quarterly Economic Commentary, Summer 2016.

Demena, Binyam A., and Peter A. G. van Bergeijk (2017), "A meta-analysis of FDI and productivity spillovers in developing countries", Journal of Economic Surveys, Vol.31, pages 546-571.

Department of Finance (2018), "Patterns of firm-level productivity in Ireland", Department of Finance, Dublin.

Girma, Sourafel, David Greenaway and Richard Kneller (2004), "Does exporting increase productivity? A microeconometric analysis of matched firms" Review of International Economics Vol.12, No. 5, pages $855-866$.

Girma, Sourafel, Holger Görg and Mauro Pisu (2008), "Exporting, linkages and productivity spillovers from foreign direct investment" in Canadian Journal of Economics, Vol. 41, No.1, pages 320-340.

Girma, Sourafel and Holger Görg (2007), "The role of the efficiency gap for spillovers from FDI: Evidence from the UK electronics and engineering sectors" in Open Economies Review, Vol. 18, pages 215-232.

Girma, Sourafel and Holger Görg (2007), "Multinational's productivity advantage: scale or technology?" Economic Inquiry, Vol. 45 No.2, pages 350-362.

Griffith, Rachel, Stephen Redding, John Van Reenen (2004), "Mapping the two faces of R\&D: Productivity growth in a panel of OECD industries", The Review of Economics and Statistics, 86(4): 883-895.

Görg, Holger and Eric Strobl (2003), "Multinational companies technology spillovers and plant survival" Scandinavian Journal of Economics, Vol. 105, No.4, page 581-595. 
Görg, Holger and Eric Strobl (2001), "Multinational companies and productivity spillovers. A metaanalysis" The Economic Journal, Vol. 111, page F723-F739.

Haller, Stefanie A. (2014), "Do domestic firms benefit from foreign presence and import competition in the Irish services sectors?" The World Economy, Vol. 37, No.2, pages 219-243.

Haskel, Jonathan E., Sonia C. Pereira, and Matthew J. Slaughter (2007), "Does inward foreign direct investment boost the productivity of domestic firms?", The Review of Economics and Statistics, 89(3), 482-496.

Havranek, Tomas and Zuzana Irsova (2011), "Estimating vertical spillovers from FDI: Why results vary and what the true effect is", Journal of International Economics, Vol.85, pages 234-244.

Javorcik, Beata (2014), "Does foreign direct investment increase the productivity of domestic firms? In search of spillovers through backward linkages" American Economic Review Vol.94 No.3, pages 605627.

Javorcik, Beata and Mariana Spatareanu (2008), "To share or not To share: Does local participation matter for spillovers from foreign direct investment?" Journal of Development Economics, 85(1-2), 194-217.

Javorcik, Beata and Mariana Spatareanu (2009), "Tough Love: Do Czech suppliers learn from their relationships with multinationals" in Scandinavian Journal of Economics, Vol. 111, No.4, pages 811833.

Javorcik, Beata S. and Mariana Spatareanu (2010), "Does it matter where you come from? Vertical spillovers from foreign direct investment and the origin of investors", in Journal of Development Economics, Vol.96, No.1, pages 126 - 138.

Jude, Cristina (2016), "Technology spillovers from FDI: Evidence on the intensity of different spillover channels", The World Economy, Vol.39, No. 12, pages 1947-1973.

Kneller, Richard and Mauro Pisu (2007), "Industrial linkages and export spillover from FDI", The World Economy, Vol.30, pages 105-134.

Levinsohn, J. and A. Petrin (2003), "Estimating production functions using inputs to control for unobservables," Review of Economic Studies, Vol.70, No.2, pages 317-341.

Love, James H. and Stephen Roper (2015), "SME innovation, exporting and growth: A review of existing evidence" International Small Business Journal, Vol.33, No.1. pages 28-48.

McQuinn, John and Iulia Siedschlag (2013), "Foreign investment and firm productivity: A meta-analysis" SERVICEGAP Discussion Paper No. 27.

Merlevede, Bruno and Koen Schoors (2009), "Openness, competition, technology and FDI spillovers: Evidence from Romania", FREIT Working Paper No.FREIT042.

Morgenroth, Edgar, Nguyen Huy Hoang, Nguyen Thi Hoang Yen, Connor O’Toole (2015), "Some further results on the spillover effects of FDI in Vietnam", chapter VII in Mai Thi Thu and Edgar Morgenroth (eds.) The Vietnamese Economy in Perspective: An Empirical Analysis, Thế Giới, Hanoi, pages 217258.

Newman, Carol, John Rand, Theodore Talbot, Finn Tarp (2015), "Technology transfers, foreign investment and productivity spillovers", European Economic Review 76, pages 168-187.

Olley, Steven G. and Ariel Pakes (1996), "The dynamics of productivity in the telecommunications equipment industry," Econometrica, Vol. 64, No.6, pages1263-1297. 
Ornaghi, Carmine, and Ilke Van Beveren (2011), "Using proxy variables to control for unobservables when estimating productivity: A sensitivity analysis", IRES Universite Catholique de Louvain Discussion Paper 2011-29

Ruane, Frances and Ali Uğur (2005), "Labour productivity and foreign direct investment in Irish manufacturing industry: a decomposition analysis", The Economic and Social Review, Vol.36, No.1, pages $19-43$.

Ruane, Frances and Ali Uğur (2004), "Foreign direct investment and productivity spillovers in Irish manufacturing industry: Evidence from plant level panel data", International Journal of the Economics of Business, Vol. 11, No.3, pages 53-66.

Timmer, Marcel, Erik Dietzenbacher, Bart Los, Robert Stehrer, and Gaaitzen de Vries, G. J. (2015), "An illustrated user guide to the World Input-Output database: the case of global automotive production", Review of International Economics., 23: 575-605.

Van Beveren, Ilke (2012), "Total factor productivity estimation: A practical review", Journal of Economic Surveys, 26(1), 98-128.

Van Biesebroeck, Johannes (2007), "Robustness of productivity estimates", The Journal of Industrial Economics, Vol. 55, No. 3, pp. 529-69.

Wooldridge, Jeffrey M. (2009), "On estimating firm-level production functions using proxy variables to control for unobservables," Economics Letters, Vol. 104, No.3, pages 112-114. 


\section{Annex A. Estimation of TFP at firm level}

1. The Wooldridge (2009) methodology uses a one-step GMM framework to improve on the previous semi-parametric estimators of input elasticities introduced by Olley and Pakes (1996), Levinsohn and Petrin (2003) and Ackerberg et al. (2006). In comparison to standard semi-parametric estimations, the approach proposed by Wooldridge (2009), accounts for the following econometric issues: ${ }^{20}$

i. the potential contemporaneous correlation of across errors in the two step approach used in standard semi-parametric methods;

ii. heteroskedasticity in the error terms;

iii. serial correlation of input choices.

2. Following Wooldridge (2009), consistent and efficient estimates of input factor elasticities are obtained for each NACE 2-digit industry with the following model specification:

$$
\begin{aligned}
v a_{i t}=\beta_{0}+\beta_{1} & k_{i t}+\beta_{2} k_{i, t-1}+\beta_{3} m_{i, t-1}+\beta_{4} k_{i, t-1}^{2}+\beta_{5} m_{i, t-1}^{2} \\
& +\beta_{6} k_{i, t-1}^{3}+\beta_{7} m_{i, t-1}^{3}+\beta_{8} k_{i, t-1} m_{i, t-1} \\
& +\beta_{9} k_{i, t-1} m_{i, t-1}^{2}+\beta_{10} k_{i, t-1}^{2} m_{i, t-1}+\delta L_{i, t-1} \\
& +\gamma \text { Yeart }+\varepsilon_{i t}
\end{aligned}
$$

3. All variables are expressed in logarithms; $v a$ denotes value added, $k$ denotes capital stock, ${ }^{21} \mathrm{~m}$ denotes materials, $L$ denotes labour and year denotes a full set of year dummies. It is assumed that capital is fixed in the short run and cannot be adjusted freely, whereas the amount of labour is chosen by firms in every time period. This implies that the choice of labour is likely correlated with TFP, which in the above model is captured in the residual $\varepsilon$, and is therefore an endogenous regressor. To circumvent this endogeneity problem, the estimation is carried out using GMM and labour is instrumented with its first lag.

4. TFP at firm level is obtained as the residual in the following equation:

$$
T F P_{i t}=v a_{i t}-\left(\beta_{0}^{\wedge}+\beta_{1}^{\wedge} k_{i t}+\delta^{\wedge} L_{i, t-1}+\gamma^{\wedge} Y e a r_{t}\right)
$$

${ }^{20}$ Van Beveren (2012) provides a detailed discussion of the approach proposed by Wooldridge (2009) in comparison to standard semi-parametric estimators of TFP.

${ }^{21}$ Capital stocks were obtained as part of the MultiProd project led by the OECD. We thank Brendan O'Connor, Javier Papa, and Luke Rehill for useful discussions and for sharing with us relevant output of the MultiProd project. 


\section{Annex B. Data}

\section{Table B.1. Variables' Definitions and Data Sources}

\begin{tabular}{|c|c|c|}
\hline Variable & Definition & Data Source \\
\hline TFP $P_{i j r t}$ & $\begin{array}{l}\text { Total factor productivity for firm } \mathrm{i} \text { in industry } \mathrm{j} \text { located in } \\
\text { region } \mathrm{r} \text { at time } \mathrm{t} \text { estimated using the Wooldridge (2009) } \\
\text { methodology. }\end{array}$ & $\begin{array}{c}\text { Department of } \\
\text { Finance, } \text { MultiProd } \\
\text { project }\end{array}$ \\
\hline$H O R_{j t}$ & $\begin{array}{l}\text { The share of foreign-owned affiliates' employment in total } \\
\text { employment of industry } j \text {, at time } t \text {. }\end{array}$ & $\begin{array}{l}\text { CIP and ASI 2008- } \\
2014\end{array}$ \\
\hline$H_{O} R_{r t}$ & $\begin{array}{l}\text { The share of foreign-owned affiliates' employment in total } \\
\text { employment of region } r \text {, at time } t \text {. }\end{array}$ & $\begin{array}{l}\text { CIP and ASI 2008- } \\
2014\end{array}$ \\
\hline$F O R_{j t}$ & $\begin{array}{l}\text { Variable capturing the intermediate inputs available from } \\
\text { foreign affiliates in upstream industries to domestic firms in } \\
\text { industry } j \text { net of imported inputs (domestically sourced } \\
\text { inputs), at time t. }\end{array}$ & $\begin{array}{l}\text { WIOD } 2014 \text { and } \\
\text { CIP and ASI 2008- } \\
2014\end{array}$ \\
\hline$B A C_{j t}$ & $\begin{array}{l}\text { Variable capturing the indigenous firms' output in upstream } \\
\text { industries available to foreign affiliates in industry } j \text { net of } \\
\text { imported inputs, based on the technology of the parent } \\
\text { company in its home country, at time t. }\end{array}$ & $\begin{array}{l}\text { WIOD } 2014 \text { and } \\
\text { CIP and ASI 2008- } \\
2014\end{array}$ \\
\hline$\Delta$ Sales $_{j t}$ & Annual growth of sales in industry $j$ at time t. & $\begin{array}{l}\text { CIP and ASI 2008- } \\
2014\end{array}$ \\
\hline$H H I_{j t}$ & $\begin{array}{l}\text { Herfindahl-Hirschman index in industry } \mathrm{j} \text { at time } \mathrm{t} \text {; the index } \\
\text { increases in market shares concentration (and decreases } \\
\text { with the level of competition). }\end{array}$ & $\begin{array}{l}\text { CIP and ASI 2008- } \\
2014\end{array}$ \\
\hline Exporter $_{i j r t}$ & $\begin{array}{l}\text { Binary variable equal to one if firm } i \text { in industry } j \text { located in } \\
\text { region } r \text { reports export sales at time } t \text { and zero otherwise. }\end{array}$ & $\begin{array}{l}\text { CIP and ASI 2008- } \\
2014\end{array}$ \\
\hline Importer $_{i j r t}$ & $\begin{array}{l}\text { Binary variable equal to one if firm } i \text { in industry } j \text { region } r \\
\text { reports imported inputs at time } t \text { and zero otherwise. }\end{array}$ & $\begin{array}{l}\text { CIP and ASI 2008- } \\
2014\end{array}$ \\
\hline Wage/Emp & $\begin{array}{l}\text { Wage per employee firm } \mathrm{i} \text { in industry } \mathrm{j} \text { located in region } \mathrm{r} \text { at } \\
\text { time } \mathrm{t} \text {. }\end{array}$ & $\begin{array}{l}\text { CIP and ASI 2008- } \\
2014\end{array}$ \\
\hline$R D_{i j r t}$ & $\begin{array}{l}\text { Binary variable equal to one if firm } i \text { in industry } j \text { located in } \\
\text { region } r \text { reports investment in } R \& D \text { at time } t \text { and zero } \\
\text { otherwise. }\end{array}$ & $\begin{array}{l}\text { CIP and ASI 2008- } \\
\qquad 2014\end{array}$ \\
\hline
\end{tabular}


Table B.2. Descriptive Statistics by Firm Ownership, All Firms

\begin{tabular}{|c|c|c|c|c|c|c|c|c|c|c|}
\hline & \multicolumn{2}{|c|}{ All Firms } & \multicolumn{2}{|c|}{ Irish-owned } & \multicolumn{2}{|c|}{ Foreign-owned } & \multicolumn{2}{|c|}{ EU-owned } & \multicolumn{2}{|c|}{ Non-EU owned } \\
\hline & Mean & Std. Dev & Mean & Std. Dev & Mean & Std. Dev & Mean & Std. Dev & Mean & Std. Dev \\
\hline Ln TFP & 2.40 & 10.53 & 2.57 & 10.51 & 1.00 & 10.59 & 1.59 & 10.76 & 0.43 & 10.40 \\
\hline Ln Capital & 13.49 & 2.01 & 13.27 & 1.88 & 15.4 & 2.04 & 15.09 & 2.02 & 15.71 & 2.02 \\
\hline Ln Labour & 2.62 & 1.48 & 2.45 & 1.38 & 4.11 & 1.44 & 3.92 & 1.45 & 4.29 & 1.41 \\
\hline Ln Intermediates & 13.59 & 2.16 & 13.32 & 1.99 & 15.94 & 2.06 & 15.59 & 1.91 & 16.27 & 2.14 \\
\hline Sector growth & -0.01 & 0.18 & -0.01 & 0.17 & 0.03 & 0.20 & -0.00 & 0.18 & 0.01 & 0.21 \\
\hline HH Index & 0.07 & 0.13 & 0.06 & 0.12 & 0.11 & 0.17 & 0.09 & 0.16 & 0.12 & 0.18 \\
\hline Exporter & 0.19 & 0.39 & 0.15 & 0.36 & 0.51 & 0.50 & 0.43 & 0.50 & 0.59 & 0.49 \\
\hline Importer & 0.14 & 0.35 & 0.11 & 0.32 & 0.37 & 0.49 & 0.38 & 0.49 & 0.39 & 0.49 \\
\hline Ln Wage per Employee & 10.08 & 0.67 & 10.01 & 0.65 & 10.63 & 0.57 & 10.52 & 0.60 & 10.72 & 0.52 \\
\hline$R \& D$ active dummy & 0.42 & 0.49 & 0.44 & 0.50 & 0.30 & 0.46 & 0.28 & 0.45 & 0.33 & 0.47 \\
\hline $\mathbf{N}$ & 69,167 & & 61,844 & & 7,323 & & 3,554 & & 3,769 & \\
\hline
\end{tabular}

Source: Authors' calculations and estimates obtained with the MultiProd model using data from Ireland's Central Statistics Office (CSO) 
Table B.3. Correlation matrix, all firms

\begin{tabular}{|c|c|c|c|c|c|c|c|c|c|c|c|}
\hline & Ln TFP & $\begin{array}{c}\text { Ln } \\
\text { Capital }\end{array}$ & Ln Labour & Ln Intermediates & Ln Age & Ln Age & $\begin{array}{c}\text { Ln } \\
\text { Wage/Emp }\end{array}$ & Exporter & Importer & HHI & $\begin{array}{l}\text { R\&D } \\
\text { active }\end{array}$ \\
\hline Ln TFP & 1 & & & & & & & & & & \\
\hline Ln Capital & -0.493 & 1 & & & & & & & & & \\
\hline Ln Labour & -0.036 & 0.751 & 1 & & & & & & & & \\
\hline Ln Intermediates & 0.062 & 0.614 & 0.774 & 1 & & & & & & & \\
\hline Sector growth & -0.044 & 0.034 & -0.001 & -0.018 & 1 & & & & & & \\
\hline Ln Wage/Employee & -0.068 & 0.352 & 0.260 & 0.394 & 0.040 & 0.161 & 1 & & & & \\
\hline Exporter & -0.075 & 0.380 & 0.360 & 0.409 & 0.008 & 0.201 & 0.310 & 1 & & & \\
\hline Importer & 0.051 & 0.284 & 0.369 & 0.394 & 0.001 & 0.162 & 0.211 & 0.401 & 1 & & \\
\hline HHI & -0.169 & 0.166 & 0.040 & 0.039 & 0.118 & 0.018 & 0.168 & 0.149 & 0.011 & 1 & \\
\hline R\&D active & 0.037 & -0.262 & -0.374 & -0.252 & 0.087 & -0.107 & -0.040 & -0.071 & -0.217 & 0.067 & 1 \\
\hline \multicolumn{12}{|l|}{ Irish-owned } \\
\hline Ln TFP & 1 & & & & & & & & & & \\
\hline Ln Capital & -0.514 & 1 & & & & & & & & & \\
\hline Ln Labour & -0.007 & 0.716 & 1 & & & & & & & & \\
\hline Ln Intermediates & 0.090 & 0.560 & 0.758 & 1 & & & & & & & \\
\hline Sector growth & -0.045 & 0.026 & -0.015 & -0.036 & 1 & & & & & & \\
\hline Ln Wage/Employee & -0.058 & 0.300 & 0.209 & 0.332 & 0.029 & 0.153 & 1 & & & & \\
\hline Exporter & -0.059 & 0.324 & 0.306 & 0.349 & 0.001 & 0.193 & 0.256 & 1 & & & \\
\hline Importer & 0.062 & 0.244 & 0.334 & 0.357 & 0.001 & 0.153 & 0.176 & 0.366 & 1 & & \\
\hline HHI & -0.167 & 0.139 & -0.001 & -0.009 & 0.123 & 0.013 & 0.147 & 0.122 & -0.006 & 1 & \\
\hline R\&D active & 0.040 & -0.289 & -0.403 & -0.276 & 0.095 & -0.114 & -0.036 & -0.073 & -0.226 & 0.066 & 1 \\
\hline \multicolumn{12}{|l|}{ Foreign-owned } \\
\hline Ln TFP & 1 & & & & & & & & & & \\
\hline Ln Capital & -0.440 & 1 & & & & & & & & & \\
\hline
\end{tabular}




\begin{tabular}{|c|c|c|c|c|c|c|c|c|c|c|c|}
\hline & Ln TFP & $\begin{array}{c}\text { Ln } \\
\text { Capital }\end{array}$ & Ln Labour & Ln Intermediates & Ln Age & Ln Age & $\begin{array}{c}\text { Ln } \\
\text { Wage/Emp }\end{array}$ & Exporter & Importer & HHI & $\begin{array}{r}\text { R\&D } \\
\text { active }\end{array}$ \\
\hline Ln Intermediates & 0.076 & 0.555 & 0.598 & 1 & & & & & & & \\
\hline Sector growth & -0.025 & 0.051 & 0.004 & 0.036 & 1 & & & & & & \\
\hline Ln Wage/Employee & -0.028 & 0.142 & -0.114 & 0.234 & 0.093 & 0.060 & 1 & & & & \\
\hline Exporter & -0.085 & 0.263 & 0.195 & 0.288 & 0.012 & 0.153 & 0.211 & 1 & & & \\
\hline Importer & 0.085 & 0.134 & 0.233 & 0.266 & 0.002 & 0.130 & 0.033 & 0.325 & 1 & & \\
\hline HHI & -0.154 & 0.161 & 0.047 & 0.072 & 0.081 & -0.009 & 0.156 & 0.148 & -0.038 & 1 & \\
\hline$R \& D$ active & -0.023 & 0.066 & -0.093 & 0.064 & 0.040 & 0.014 & 0.163 & 0.093 & -0.098 & 0.147 & 1 \\
\hline
\end{tabular}

Source: Authors' calculations and estimates obtained with the MultiProd model using data from Ireland's Central Statistics Office (CSO). 


\section{OECD PRODUCTIVITY WORIING PAPERS}

OECD Productivity Working Papers are published on oe.cd/GFP

01. Institutions to promote pro-productivity policies: Logic and Lessons (November 2015) by Gary Banks

02. Frontier Firms, Technology Diffusion and Public Policy: Micro Evidence from OECD Countries

(November 2015) by Dan Andrews, Chiara Criscuolo and Peter N. Gal.

03. Policies for productivity growth

(March 2015) by Chang-Tai Hsieh

04. Could Mexico become the new "China" Policy drivers of competitiveness and productivity

(July 2016) by Sean M. Dougherty and Octavio R. Escobar

05. The Best versus the Rest: The Global Productivity Slowdown, Divergence across Firms and the Role of Public Policy

(November 2016) by Dan Andrews, Chiara Criscuolo and Peter N. Gal

06. What makes cities more productive? Agglomeration economies and the role of urban governance: Evidence from 5 OECD countries

(February 2017) by Rudiger Ahrend, Emily Farchy, Ioannis Kaplanis and Alexander C. Lembcke

07. Pro-Productivity Institutions: Learning From National Experience (April 2017) by Andrea Renda and Sean Dougherty

08. The impact of structural reforms on productivity: The role of the distance to the technological frontier

(May 2017) by Gustavo Monteiro, Ana Fountoura Gouveia and Sílvia Santos

09. Product markets' deregulation: A more productive, more efficient and more resilient economy?

(September 2017) by Gustavo Monteiro, Ana Fountoura Gouveia and Sílvia Santos

10. Achieving New Zealand's productivity potential

(October 2017) by Paul Conway

11. The Contribution of Multinational Enterprises to Labor Productivity: The Case of Israel

(February 2018) by Tatiana Slobodnitsky, Lev Drucker and Assaf Geva

12. GVCs and centrality: mapping key hubs, spokes and the periphery

(February 2018) by Chiara Criscuolo and Jonathan Timmis

13. Fear the walking dead: zombie firms, spillovers and exit barriers (June 2018) by Ana Fontoura Gouveia and Christian Osterhold

14. GVC centrality and productivity: Are hubs key to firm performance? (June 2018) by Chiara Criscuolo and Jonathan Timmis

15. Patterns of firm level productivity in Ireland (September 2018) by Javier Papa, Luke Rehill and Brendan O'Connor 


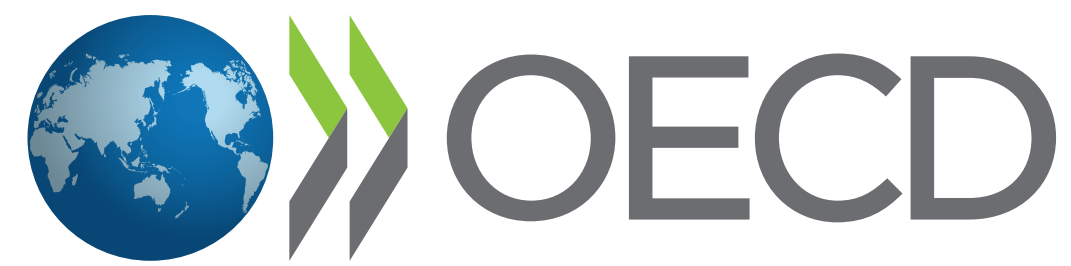

BETTER POLICIES FOR BETTER LIVES 